\title{
Molecular studies on the Creole cattle breed in Mauritius
}

\author{
Olivier Pasnin ${ }^{1}$, V. M. Ranghoo-Sanmukhiya ${ }^{2 *}$ \\ ${ }^{1}$ Mauritius Oceanography Institute, Quatre-Bornes, Mauritius \\ ${ }^{2}$ Department of Agriculture and Food Science, Faculty of Agriculture, The University of Mauritius, Réduit, Mauritius \\ Email: ${ }^{\text {m.sanmukhiya@uom.ac.mu }}$
}

Received 30 June 2013; revised 15 July 2013; accepted 2 August 2013

Copyright (C) 2013 Olivier Pasnin, V. M. Ranghoo-Sanmukhiya. This is an open access article distributed under the Creative Commons Attribution License, which permits unrestricted use, distribution, and reproduction in any medium, provided the original work is properly cited.

\begin{abstract}
There are three main cattle breeds in Mauritius; the Friesian cows, the Creole cows and the Cross (Creole and Friesians) breeds. The main objective of the study was to differentiate the Creole breeds from the other two breeds thus valorizing and conserving the Creole cow which is in danger of extinction. Random Amplified Polymorphic DNA and random microsatellite analysis were the two PCR based techniques used. The populations studied consisted of 5 Friesians, 5 Creole breeds and 5 Cross breeds. The breeds were obtained from the Curepipe Livestock Research Station which is the only place where there is a record of Creole cows in Mauritius. Among the 5 Creoles breeds chosen, 2 of them could have been impure breeds due to their morphological characteristics. DNA extraction was carried out from blood taken from the cows selected, and yielded DNA of good quality and quantity. Polymorphic bands were obtained from the Random Amplified Polymorphic DNA primers and random microsatellite primers and the data obtained were used for constructing a dendogram. From the dendogram obtained, the breeds were separated and the two Creole samples, which were suspected to be impure, formed different clusters from the true Creole breeds. From the results obtained, the Creole breed was easily distinguishable from the other breeds studied using molecular techniques.
\end{abstract}

Keywords: Creole Cows; Friesian Cows; DNA Extraction; Microsatellites; RAPDS

\section{INTRODUCTION}

There are three main cattle breeds in Mauritius which are

\footnotetext{
"Corresponding author.
}

the Friesian, the Creole and the Cross (Creole and Friesians) breeds which are kept on a small scale as a side activity in some household [1]. The first cattle breed to exist in Mauritius was probably the Zebus or Sangas which was introduced by the Portuguese in year 1511 and afterwards the Ongle, Mysore and Hissar cattle were imported from India by sugar estates. The breed Afrikanders were also introduced as Zebu herds and in 1922, Friesian cattle were imported from South Africa to start dairy herd. There is no proved explanation on the origin of the Creole cow in Mauritius but everybody seems to agree that it originates from north Europe and most probably came through France if not from France [1]. According to Bennie [2], it is possible that this breed was introduced in the eighteenth century although the first introduction of cattle dated back to 1511 .

The Creole cattle breed found in Mauritius has been declining drastically mainly due to the introduction of new breeds such as the Friesian cattle. Thus, while the Creole cattle represented over 77\% (32,332 heads out of 41,968 ) of the cattle population in 1964 [3] and in 2001 it represented less than $8 \%$ with 274 heads out of 3781 adult animals [1]. The Creole cows have adapted themselves quite perfectly to the environment and low level of nutrition in Mauritius. They are known to be resistant to diseases and have interesting potential both in terms of production and reproduction. In 1944 a decision was made to cross the Friesian breed with the Creole one through artificial insemination leading to the production of the Cross breeds [1].

The physical characterization of the Creole breed showed that it is different from the other breeds found in Mauritius. It is characterized by its white colour, an absence of hump and its polledness. The creole breeds are actually used for milk production and used for beef production. The breed continues to decline each year and a molecular characterization is essential for preventing germplasm erosion and also to obtain the information necessary on this particular breed. 
RAPD markers and analysis have many advantages over other methods of examining polymorphism due to their ease and simplicity compared to other marker systems. RAPD markers have actually been widely used in the characterization of livestock breeds [4-6]. Microsatellites form part of the most common markers used for genetic characterization of cattle breeds [7-9]. In transgenic breeding, molecular markers can be used as reference points for the identification, isolation and manipulation of relevant genes, and for identification of animals carrying the transgenes [10]. The use of microsatellites as a genetic appraisal tool is quite significant [11]. Microsatellites can detect rare alleles compared to other markers [12]. Many researchers are now using microsatellites due to its various advantages compared to other markers. The detection of microsatellite polymorphism results in the greatest expected heterozygosity [13]. Microsatellites polymorphisms enable differentiation, even between closely related breed, more clearly and also increase the accuracy of the predicted divergence [14]. Microsatellites are proved to be useful in the probability of sample identity at population levels [15].

\section{MATRIALS AND METHODS}

\subsection{Animal Samples}

The animal breeds included 5 Friesians, 5 Creoles breeds and 5 Cross breeds. They were obtained from the Curepipe Livestock Research Station where there is a record of Creole cows in Mauritius.

\subsection{DNA Isolation Protocol and Purification}

Genomic DNA was extracted from peripheral blood and use of fresh blood was essential to obtain a good yield of DNA. The blood was stored in sterilized tubes containing EDTA solution as heparin can cause inhibition of PCR amplification [16]. A two step protocol was used for the DNA extraction. The first step was the extraction of genomic DNA from white blood cells pellet and the second step involved the extraction of DNA from cell lysis solution using organic solvents. The first step was done on the first day and the white blood cells were inoculated in SDS solution at $37^{\circ} \mathrm{C}$ overnight and on the following day the second step was carried out. The DNA obtained was stored in about $200-300 \mu \mathrm{l}$ nano pure water at $-20^{\circ} \mathrm{C}$.

\subsection{PCR Reaction}

The thermal cycle used for the RAPD PCR was 5 minutes for initial denaturation step at $94^{\circ} \mathrm{C}$, followed by 38 cycles at $94^{\circ} \mathrm{C}$ for 30 seconds for denaturation step, $35^{\circ} \mathrm{C}$ at 30 seconds for annealing step, 2 minutes at $72^{\circ} \mathrm{C}$ for extension and finally a 10 minutes at $72^{\circ} \mathrm{C}$ for final extension. 50 RAPD primers were screened. The same protocol and thermocycling conditions as for the RAPD PCR were used for the screening of 50 random microsatellites primers, except for the annealing temperature which was $56.5^{\circ} \mathrm{C}$.

\subsection{DNA Profile Analysis}

Each genotype was characterized by its banding pattern using the DNA hyperladder 2 (Bioline) as base pair ladder. The microsatellite and RAPD markers as viewed from the gels after electrophoresis and staining were converted into a matrix of binary data, where the presence of the band corresponded to value 1 and the absence to value 0 . The statistical software NTSYS-PC [17] and DARwin 5 software [18] were used to construct a UPGMA dendrogram using hierarchical clustering. Using NTSYS software, a dissimilarity matrix was calculated utilising Jaccard's coefficient [19]. The matrix was converted to a dissimilarity matrix corresponding to the complement (dissimilarity $=1-$ similarity). Cluster analysis based on the dissimilarity matrix, was performed using un-weighted pairgroup method arithmetic averages (UPGMA) [20] of the NTSYS-PC version 2.2.

\section{RESULTS}

Maximum polymorphism was obtained using OPJ16 (CTGCTTAGGG) (Figure 1), OPA10 (GTGATCGCAG) (Figure 2) and OPY18 (GTGGAGTCAG) (Figure 3). Out of microsatellites primers screened maximum polymorphism was obtained using microsatellite primers TTCX5 (Figure 4) and GTAGX4 (Figure 5). Both microsatellite markers and RAPD markers were found to be suitable for the assessment of genetic diversity among the different cattle breeds in Mauritius.

Two major clusters were observed in the dendogram produced using RAPD and SSR markers (Figure 6) clearly distinguishing between the Creole breed and the Friesian breed. There was one Creole cattle which clustered with the Cross breed while a cattle from the Cross breed clustered with the Friesian breed.

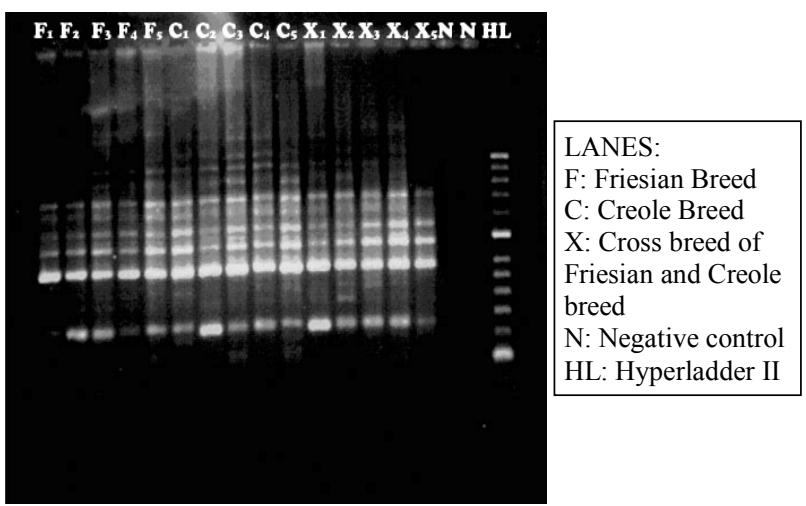

Figure 1. RAPD amplification using primer OPJ16. 


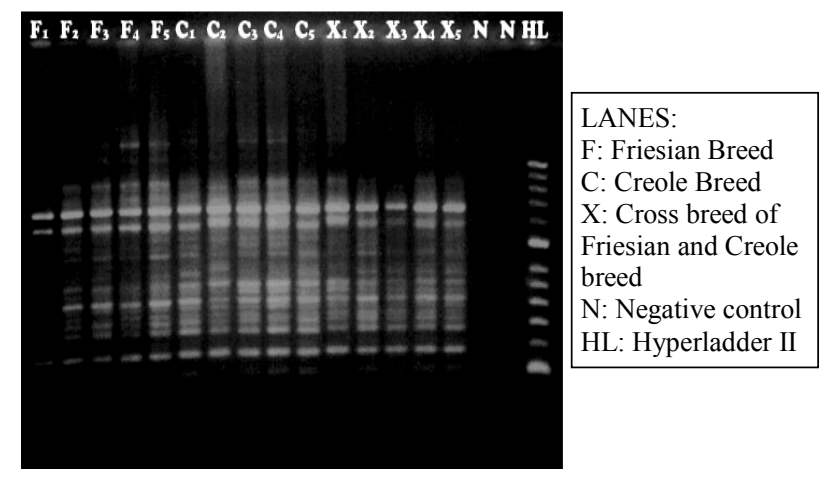

Figure 2. RAPD amplification using primer OPA10.

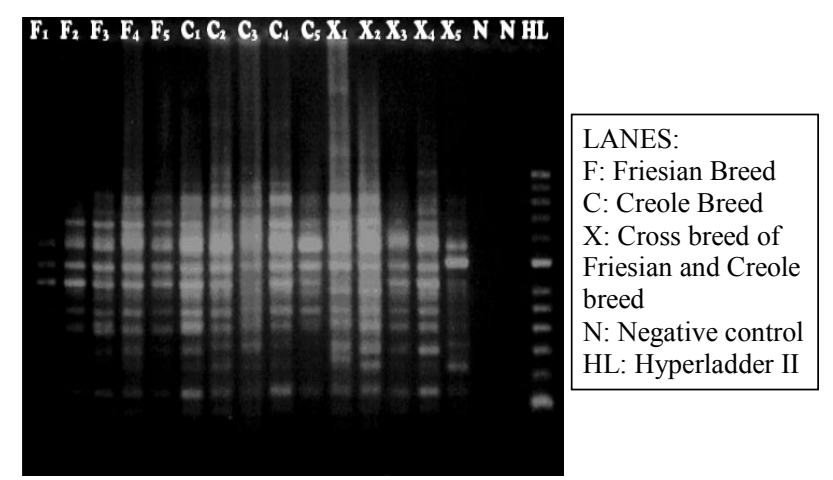

Figure 3. RAPD amplification using primer OPY18.

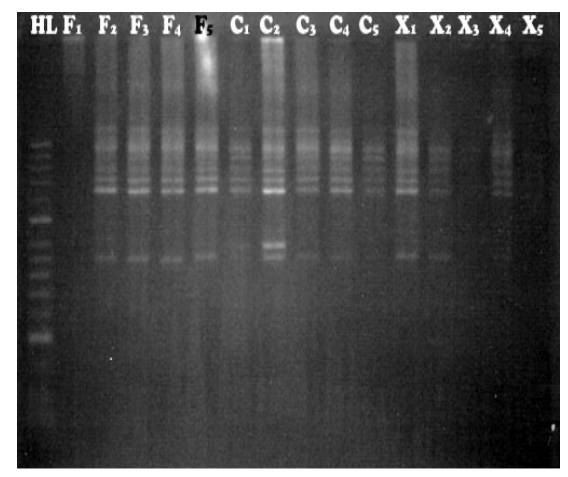

Figure 4. Microsatellite amplifications using primer TTCX5.

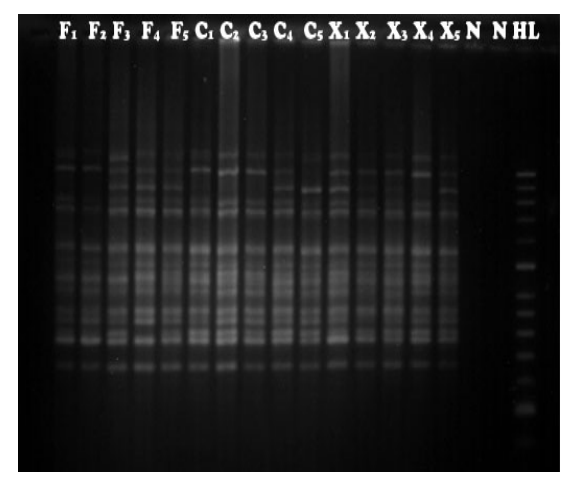

Figure 5. Microsatellite amplifications using primer GTAGX4.

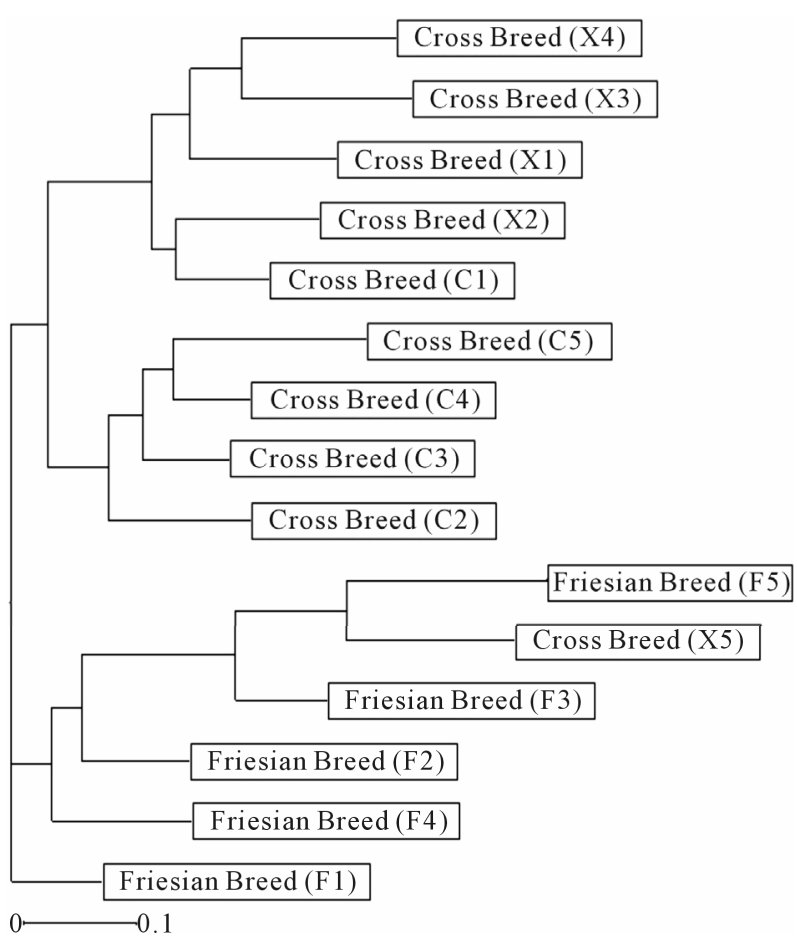

Figure 6. Dendogram showing relationships between the cattle breed studied using RAPD and SSR markers.

\section{DISCUSSION}

Phenotypically the three cattle breeds are different, showing different morphological characters. The body coat of the Creole cow is white with a pink muzzle, white ears and white eyelids. The body coat of the Friesian is however black with a black muzzle, black ears and black eyelids. The body coat of the Cross breed is however intermediate white and black with a pigmented muzzle, brown ears and white eyelids. The most striking morphological feature is the presence of horn in the Friesian breeds and the cross-breed and this feature is absent in the Creole cows.

The dendogram (Figure 6) obtained from both RAPD and microsatellite primers confirm the difference which exists between the cattle breeds, particularly the Friesian and Creole cows. The Friesian cows as expected formed a different cluster from the Creole breed and Cross breed confirming genetically the difference which is seen in the morphological characteristics.

Ideally the expected results for the classification of the Creole breed would have been a cluster of all the 5 Creoles in a single cluster. This would have shown that the Creole breeds are genetically different from the other breeds. However, 2 clusters were formed (Figure 6) one containing 4 individuals of the Creoles breed and another with one Creole breed and the Cross breed. The fact that the Creole cows were classified in two separate clusters can be explained by the following reasons: There are few 
Creole cows in Mauritius and among the limited number remaining only a few of them may be really pure breed. Moreover, the Creole cows are crossed with the Cross breeds of Creole and Friesian, therefore the new born calves cannot be said to be pure Creole breeds as they contained some of the characteristics of the Cross breeds, either expressed or not. From the selected Creole cows at the experimentation station, it was easy to distinguish if the Creole cows were potentially pure breed or not. Some good samples were unavailable and other cows were selected as alternatives but they were not pure breeds. Observing the morphological characteristics and the dendogram obtained from RAPD primers, one of the Creole cows which formed a different cluster from the other three samples was not pure breed. Presence of horns in that Creole cow was one of the characteristics which showed that it was not a pure breed.

From the result obtained above it can be hypothesized that existing Creole Cattle breed are not pure breed and that there may have been considerable crossing which have inadvertedly happened over time explaining why the Creole cattle breed and the Cross breed cluster together in the same clade. Therefore there is an urgent need to salvage the remaining pure cattle breed if we wish to preserve the beneficial reproductive and productive traits in the cattle gene pool.

\section{CONCLUSION}

The cattle breeds are phenotypically different from each other and they can be easily differentiated by their physical characteristics. Assessing the differences at the molecular level was a more tedious work. The RAPD and microsatellite primers, as expected, gave good amplification and, sharp and clear polymorphic bands were observed and these markers have shown that the Creole cows are different from the Friesian cows. The creole cattle breed has good agronomic traits namely production and reproduction and there is an urgent need that a solid conservation programme be implemented if this breed is to be saved from extinction as a large amount of crossing has been noted and it is difficult to say whether there still exist a pure Creole Cattle Breed in Mauritius [1].

\section{ACKNOWLEDGEMENTS}

We wish to acknowledge the Faculty of Agriculture, University of Mauritius for the laboratory facilities provided and the Agricultural Research and Extension Unit for providing the cow samples.

\section{REFERENCES}

[1] Lam Sheung Yuen R., (2005) Characterisation of the Creole cattle in Mauritius. Food and Agricultural Research Council, Reduit.
[2] Bennie, J.S.S., (1956) The Mauritian Creole breed of milch cattle. Empire Journal of Experimental Agriculture, 24, 95.

[3] Livestock Statistics (1966) Livestock statistics for 1950, 1956 and 1964. Department of Agriculture, Mauritius.

[4] Nagaraja, C.S., Rasool, T.J., Govindaiah, M.G. and Jayashankar, M.R. (2003) Genetic characterization of certain Indian cattle breeds by random amplification of polymorphic DNA. Indian Veterinary Journal, 80, 906-909.

[5] Bhattacharya, T.K., Kumar, P. and Joshi, J.D. (2004) Use of RAPD markers for genetic divergence study in cattle. Indian Journal of Animal Science, 74, 220-222.

[6] Saifi, H.W., Bhushan, B., Kumar, P., Patra, B.N. and Sharma, A. (2004) Genetic identity between Bhadawari and Murrah breeds of Indian buffaloes (Bubalus bubalis) using RAPD-PCR. Asian-Australasian Journal of Animal Science, 17, 603-607.

[7] MacHugh, D.E., Loftus, R.T., Bradley, D.G., Sharp, P.M. and Cunningham, E.P. (1994) Microsatellite DNA variation within and among European cattle breeds. Proceedings of the Royal Society B, 256, 25-31. http://dx.doi.org/10.1098/rspb.1994.0044

[8] Kantane, J., Olsaker, L., Holm, L.E., Lien, S., Vilkki, J., Brusgaard, K., Eythorsdottir, E., Danell B. and Adalateinsson, S. (2000) Genetic diversity and population structure of twenty North European cattle breeds. The American Genetic Association, 91, 446-457.

[9] Moazami-Goudarzi, K, Furet, J.P., Grosclaude, F., and Laloë, D. (2003) Analysis of genetic relationships between 10 cattle breeds with 17 microsatellites. Animal Genetics, 28, 338-345. http://dx.doi.org/10.1111/j.1365-2052.1997.00176.x

[10] Das, H.K. (2005) Textbook of biotechnology. 2nd Edition, Wiley Dreamtech India (P) Ltd., Rajajinagar.

[11] Olowofeso, O., Wang, J.Y., Dai, G.J., Yang, Y., Mekki, D.M. and Musa, H.H. (2005) Measurement of genetic parameters within and between Haimen chicken populations using microsatellite markers. International Journal of Poultry Science, 4, 143-148. http://dx.doi.org/10.3923/ijps.2005.143.148

[12] Bartfai, R., Egedi, S., Yue, G.H., Kovacs, B., Urbanyi, B., Tamas, G., Horvath, L. and Orban, L. (2003) Genetic analysis of two common carp broodstock by RAPD and microsatellite markers. Aquaculture, 219, 157-167. http://dx.doi.org/10.1016/S0044-8486(02)00571-9

[13] Powell, W., Morgante, M., Andre, C., Hanafey, M., Vogel, J., Tingey, S. and Rafalski, A. (1996) The comparison of RFLP, RAPD, AFLP and SSR markers for germplasm analysis. Molecular Breeding, 2, 225-238. http://dx.doi.org/10.1007/BF00564200

[14] Zhang, X., Leung, F.C., Chan, D.K.O., Yang, G. and Wu, C. (2002) Genetic diversity of Chinese native chicken breeds based on protein polymorphism, randomly amplified polymorphic DNA, and microsatellite polymorphism. Journal of Poultry Science, 81, 1463-1472.

[15] Ya-Bo, Y., Jin-Yu, W., Mekki, D.M., Qing-Ping, T., HuiFang, L., Rong, G., Qing-Lian, G., Wen-Qi Z. and KuanWei, C. (2006) Evaluation of genetic diversity and ge- 
netic distance between twelve Chinese indigeneous chicken breeds based on microsatellite markers. International Journal of Poultry Science, 5, 550-556. http://dx.doi.org/10.3923/ijps.2006.550.556

[16] Yokata, M., Tatsumi, N., Nathalang, O., Yamada T. and Tsuda, I. (1999) Effects of heparin on PCR for blood white cells. Journal of Clinical Laboratory Analysis, 3, 133-140.

http://dx.doi.org/10.1002/(SICI)1098-2825(1999)13:3<13 3::AID-JCLA8 $>3.0 . \mathrm{CO} ; 2-0$

[17] Rohlf, F.J. (2005) NTSYSpc (Numerical Taxonomy \&
Multivariate Analysis System). Version 2.2, Exeter Software, Applied Biostatistics Inc., New York.

[18] Perrier, X. and Jacquemoud-Collet, J.P. (2006) DARwin software. http://darwin.cirad.fr/Darwin

[19] Jaccard, P. (1908) New research on the floral distribution. Bulletin des Seances Société Vaudoise des Sciences Naturelles, 44, 223-270.

[20] Sneath, P.H.A. and Sokal, R.R. (1973) Numerical taxonomy. W.H. Freeman and Co., New York. 